\title{
Explorando um gênero literário: os romances de cavalaria ${ }^{1}$
}

\author{
Marcos Antônio Lopes ${ }^{2}$
}

Focando a produção da obra literária em perspectiva histórica, o artigo aborda uma série de aspectos relacionados ao universo temático dos romances de cavalaria. Em abordagem generalizante, o texto analisa o advento e evolução do gênero romance de cavalaria, expõe alguns elementos centrais de sua estrutura interna, concluindo com algumas das funções sociais desta literatura.

Palavras-chave: História e literatura - romance histórico - historiografia

\section{Exploring a literary gender: the chivalry novels}

This article deals with a series of aspects related to the thematic universe of the chivalry novels, focusing on the production of the literary work from a historical perspective. The text analyzes the advent and evolution of the genre chivalry novels, presents some central elements of its internal structure, concluding with some of the social functions of this kind of literature.

Keywords: History and literature - historical novel - historiography

\section{Explorant un gendre littéraire: les romans de chevalerie}

Cet article traite d'une série d'aspects en rapport avec l'univers thématique des romans de la chevalerie et se concentre sur la production du travail littéraire d'une perspective historique. Le texte analyse la naissance et évolution du genre des romans de la chevalerie, présente quelques éléments centraux de sa structure interne et conclut avec quelques-uns des fonctions sociales de ce genre de littérature.

Mots clés: Histoire et littérature - roman historique - historiographie

\footnotetext{
${ }^{1}$ Artigo recebido e aprovado para publicação em julho de 2009.

${ }^{2}$ Doutor em História pela Universidade de São Paulo E-mail: malopes@uel.br.
} 
A ética feudal, a representação ideal do cavaleiro perfeito, portanto, atingiu uma considerável e duradoura influência.

(...) Assim, o ideal cavaleiresco sobreviveu a todas as catástrofes que feriram o feudalismo no decorrer dos séculos.

Sobreviveu mesmo ao Dom Quixote de Cervantes, que interpretou o problema da maneira mais perfeita.

Eric Auerbach. Mimesis.

Os romances são os romances! São lidos e aquilo que se lê se esvai em cinzas! Não. Os romances cavalheirescos fizeram carreira. Foram postos em prática. Suscitaram instituições. Forneceram programas de conduta e de ação. Modelaram os cérebros e as almas.

Lucien Febvre. Honra e Pátria.

Reconhecemos esse tom patriótico e lealista próprio às histórias tradicionais da França. (...) Conservamos, qualquer que seja a época da ação, os temas nunca inteiramente esquecidos dos velhos romances de cavalaria.

Philippe Ariès. O Tempo da História.

Em Miguel de Cervantes vemos como o seu humor extraordinário deu vida à figura do maior escavador de precipícios da história da literatura. Possuído pela energia anacrônica do heroísmo da literatura cortês da Idade Média, Dom Quixote não perde a oportunidade de bradar suas palavras de ordem: "Tenho satisfeito agravos, castigado insolências, vencido gigantes e atropelado vampiros”. A figura do Quixote se tornou sinônimo de idealismo enlouquecido, porque a sua missão é nada menos do que a de fazer ressurgir no mundo, "com mui honrada determinação", o ideal da cavalaria andante dos bons e gloriosos tempos de Lancelote do Lago, de Amadis de Gaula e de todos os grandes paladinos da Europa. Como afirma um historiador francês, "na época de Dom Quixote, Cervantes zombou dos romances de cavalaria que ainda existiam e do público que aceitava seus efeitos de credibilidade e seus códigos narrativos". ${ }^{3}$ Apesar de centrar-se nas peripécias de um grande

\footnotetext{
${ }^{3}$ Jean-Marie Goulemot. "Da Leitura como produção de sentidos”. In: Roger Chartier (org.). Práticas de leitura. São Paulo: Estação Liberdade, 2001. p. 113. A afirmativa de Jean-Marie Goulemot é consensual. Mas há algo mais do que isso. Para uma análise de outras intenções de Cervantes no processo de elaboração de seu romance consulte-se José García López. "Cervantes y el Quijote”. In: Historia de la Literatura Española, Barcelona, Editorial Vicens Vives, 2004. p. 284.
} 
cabeça tonta, Cervantes fez uso de um consistente aterramento histórico que lhe serviu de base para as piruetas espetaculares do fidalgo manchego. Pelo recurso da paródia a um gênero literário que gozou de grande prestígio por longo tempo na Europa medieval, prestígio esse que avançou pelos Tempos Modernos, Cervantes construiu aquela que é, talvez, a maior figura ficcional da tradição literária do Ocidente. Segundo a análise de Antoine Compagnon, seu livro é "obra de interseção" do romance de cavalaria e do romance moderno, exigindo de seu público uma familiaridade com o gênero que pretende parodiar. ${ }^{4}$

Então, a propósito de recordar as peripécias do cavaleiro andante naquele que é o grande antimanual de cavalaria, aproveita-se para falar também daquela verdadeira relíquia cultural que ofereceu a substância para a composição do personagem de Cervantes: o romance cortês da Idade Média, ou seja, os autênticos romances medievais de cavalaria. E como explicar as singularidades desse gênero literário que alcançou, com as características originais bastante alteradas, naturalmente, o século XVII europeu? Recorrendo a Montesquieu, por exemplo, ainda que este recurso pareça arbitrário. Com efeito, à moda iluminista, que defende os direitos da razão em detrimento das representações simbólicas, o autor de Do Espírito das Leis oferece uma ampla definição desses romances, não sem fazer uso de um sutil senso de humor:

Como nos duelos os campeões estivessem armados de todas as peças, e como, com armas pesadas, ofensivas e defensivas, as de certa têmpera e de certa força representassem vantagens infinitas, a crença em armas encantadas de alguns combatentes deve ter transtornado o juízo de muita gente. Disso nasceu o maravilhoso sistema da cavalaria. Todos os espíritos abriram-se para essas ideias. Viram-se, nos romances, paladinos, necromantes, fadas, cavalos alados ou dotados de inteligência, homens invisíveis ou invulneráveis, mágicos que se interessavam pelo nascimento e pela educação de grandes personagens, e ainda palácios encantados e desencantados; em nosso mundo, um mundo novo; e o curso da natureza deixado somente para os homens comuns. Paladinos sempre armados em uma parte do mundo cheia de castelos, de fortalezas e de malfeitores, consideravam uma honra punir a injustiça e defender os fracos. Disso nasceu ainda, nos romances, a galanteria, fundada na ideia do amor ligada à de força e de proteção. (...) Nossos romances de cavalaria enalteceram esse desejo de agradar e deram a uma parte da Europa esse espírito de galanteria, do qual se pode dizer ter sido pouco conhecido pelos antigos. ${ }^{5}$

\footnotetext{
${ }^{4}$ Cf. Antoine Compagnon, O demônio da teoria: literatura e senso comum, Belo Horizonte, Editora UFMG, 2001, p. 208ss.
}

${ }^{5}$ Montesquieu, Do Espírito das Leis, São Paulo, Abril Cultural, 1979. p. 434s. 
De fato, no tempo das Cruzadas, e bem depois de cessado esse fenômeno histórico de longa duração, a figura do cavaleiro estava ligada ao indivíduo que, pertencendo à nobreza, não herdara bens de família, a não ser os recursos necessários para a aquisição de suas armas, além da dignidade que lhe conferia o direito de sagrar-se cavaleiro. Isso só era possível após um longo aprendizado, que incluía etapas como palafreneiro, pajem e escudeiro de um senhor de expressão no interior da ordem feudal, normalmente um ancião de sua linhagem que, a partir desse rito de passagem, tornava-se seu suserano. Esses fidalgos levavam uma existência apertada no interior da ordem aristocrática feudal. Quando se lançavam à vida aventurosa, o faziam premidos pelas necessidades de sua condição. As turbulências da juventude feudal têm a sua origem no interior do círculo familiar: "Conflito com o pai, conflito sobretudo com o irmão mais velho, herdeiro dos bens paternos. Muitos desses jovens são precisamente filhos mais novos, e essa situação contribui fortemente para o seu vaguear.” ${ }^{\text {A }}$ condição de secundogênitos em famílias normalmente numerosas mal lhes propiciava os recursos para a aquisição e manutenção de suas armas. Segundo o medievalista francês Edouard Perroy, no século XI uma couraça de cavaleiro custava o equivalente aos rendimentos agrícolas de uma gleba de proporções médias. ${ }^{7}$ Armar-se cavaleiro e arcar com os custos das peças ofensivas e defensivas de armamento, cavalo apropriado e escudeiro, implicava em consideráveis despesas que, no interior da ordem aristocrática, apenas uma minoria privilegiada podia sustentar em sua própria região de origem. Com o tempo, a cavalaria foi se tornando hereditária, e os grandes cavaleiros passaram a se distinguir pelos brasões de família.

Originadas em grande medida por necessidades dessa natureza, as aventuras cavaleirescas não poderiam deixar de ser a história de roubos, de raptos e de outras tantas ações em que a virilidade virtuosa era o principal elemento de definição. Soi Preux era a palavra de ordem dos cavaleiros franceses na Idade Média. E toda rapinagem cavaleiresca podia ficar encoberta já que, ser valente, era possuir liberdade de ação para garantir o próprio sustento. "Os valores que fundamentam a

\footnotetext{
${ }^{6}$ Jacques Le Goff. "Esboço de análise de um romance cortês". In: O maravilhoso e o quotidiano no Ocidente medieval, Lisboa, Edições 70, 1985. p. 152. Acerca das características centrais do romance cortês dos séculos XII e XIII ler o ensaio de Eric Auerbach. "A saída do cavaleiro cortês". In: Mimesis. São Paulo: Perspectiva, 2001. p. 107ss.

${ }^{7}$ Cf. Edouard Perroy, “A nova primavera da Europa: séculos XI-XII”. In: A Idade Média. São Paulo, Difel, 1974. p. 13s.
} 
ideologia cavaleiresca”, escrevia Georges Duby, “a exaltação da proeza, da rapina, da festa dos sentidos e da alegria de viver, evidentemente são construídos a partir de uma recusa resoluta do espírito de penitência e das renúncias pregadas pelos homens da oração". Naturalmente, o catálogo dos valores morais no interior da ordem cavaleiresca possuía o seu grau específico de complexidade. Nesse sentido, as fronteiras que separavam ou uniam as virtudes eram muito tênues e, em certos momentos, valentia e crueldade podiam adquirir sentidos equivalentes.

A justiça da época não via problemas reais em duelos, roubos e assassinatos, considerados pecadilhos sem relevo quando cometidos por cavaleiros. Aliás, o chamado "grito do sangue" - o duelo - era ilícito aos burgueses. No interior da ordem aristocrática, os nobres julgavam-se merecedores de uma morte heróica. A não ser em casos excepcionais considerados hediondos, como a história de um cavaleiro que assassinou a própria mulher, sendo atirado ao rio dentro de um saco costurado. Nesse caso, o crime foi punido com uma morte considerada indigna. Como lembra Perroy, "não há pior castigo para um cavaleiro do que ser tratado como vilão".' Conforme explica um escritor do Antigo Regime, Montesquieu, a vilania feria os códigos de honra dos cavaleiros medievais e constituía-se em injúria, a ser lavada com sangue. Apenas os vilões poderiam receber golpes na face, pois somente eles combatiam com o rosto descoberto. Um cavaleiro que tivesse recebido uma bofetada no rosto "havia sido tratado como vilão". ${ }^{10}$

Aos romances de cavalaria dos finais da Idade Média e dos inícios da Época Moderna coube a tarefa de dissimular as vagabundagens heróicas dos velhos tempos. A literatura criou a ilusão de que as virtudes viris dos cavaleiros andantes eram mesmo a realização de um ideal de justiça. Na teoria, após a investidura, o cavaleiro se tornava um servo de Cristo e, a partir dos séculos XII e XIII, as guerras que travava tinham suas normas estabelecidas pela Igreja. ${ }^{11} \mathrm{~A}$ cavalaria era um estilo de vida marcado por regras de civilidade definidas pelas autoridades eclesiásticas: "Ainsi une discrimination, d'intérêt capital, s’introduisait dans le vieil idéal de la guerre pour la guerre, ou pour le gain. Avec ce glaive, l'adoubé

\footnotetext{
${ }^{8}$ Georges Duby, "História social e ideologias das sociedades", In: Jacques Le Goff \& Pierre Nora. (org.), História: novos problemas, Rio de Janeiro, Francisco Alves, 1998, p. 142.

${ }^{9}$ Edouard Perroy, “Em busca da expressão literária e estética”, in: op. cit., p. 222.

${ }^{10}$ Cf. Montesquieu, Do Espírito das Leis, p. 433.

${ }^{11}$ Cf. Philip Bobbit, A guerra e a paz na história moderna, Rio de Janeiro, Campus, 2003. p. 79.
} 
défendra la Sainte Église, particulièrement contre les païens. Il poursuivra les malfaiteurs."12 A partir do século XI a Igreja assumiu o controle do cerimonial da investidura, e a sagração do cavaleiro ganhou uma nova complexidade. Ao adubamento ${ }^{13}$ do cavaleiro antecedia a vigília das armas, na qual ele ouvia a missa para, só depois de uma noite de orações, receber as armas das mãos de um clérigo. "Quanto ao tapa", lembra o medievalista francês Jean Flori, "ele tem por única função trazer ao cavaleiro a lembrança daquele que o investiu". ${ }^{14}$ Após a investidura, tornava-se um cristão defensor de sua fé. O seu compromisso, assumido com todos os efeitos de uma missão cristã, era o de proteger a Igreja, as viúvas, os órfãos, os peregrinos, os pobres e os oprimidos de todas as extrações. Nobres sem chão, ou melhor, sem a posse de terras, ao sagrarem-se cavaleiros, saíam em busca de uma vida aventurosa.

De acordo com a interpretação de alguns medievalistas, os "bons e gloriosos" tempos da literatura cavaleiresca parecem coincidir com os séculos XII e XIII. Essa foi a época de maior esplendor da cavalaria medieval. O prestígio dessa instituição militar nas sociedades de época deu origem a uma rica literatura ilustrativa de seus valores morais. Como instituição essencialmente militar, e sem desconsiderar as suas motivações religiosas, a cavalaria existiu em toda a Europa. Mas foi a França a sua pátria de origem. De fato, a literatura derivada desse fenômeno constituiu-se, durante longo tempo, em um produto francês de exportação. Entretanto, a cavalaria foi igualmente forte na Inglaterra, em Portugal, na Itália e na Alemanha. Na pátria de Dom Quixote ela também existiu, acompanhada de rica literatura, sob a influência direta da tradição francesa. Dentre algumas das ordens cavaleirescas mais importantes destacaram-se a dos Templários, a dos Hospitalários, a de Aviz, a de Calatrava e a dos Cavaleiros Teutônicos. Historiadores da Idade Média acreditam que as matrizes históricas mais remotas das ordens cavaleirescas estejam associadas

\footnotetext{
${ }^{12}$ Marc Bloch, "Le code chevaleresque", In: La société féodale, Paris, Albin Michel, 1968, p. 443.

${ }^{13}$ Do francês medieval adoubement, aqui aplicado no sentido de "equipado", "munido" dos instrumentos necessários. Acerca do complexo cerimonial de investidura do cavaleiro, incluindo a guarda de armas e o banho simbólico, ver: Georges Duby. "O século XIV”, In: A Idade Média na França, Rio de Janeiro, Zahar, 1990, p. 261; J. Flori, “Cavalaria”, In: Jean Claude Schmitt \& Jacques Le Goff, Dicionário temático do Ocidente medieval, Bauru: Edusc, 2002, vol. 1. p. 193s.; Jean Flori, A Cavalaria: a origem dos nobres guerreiros da Idade Média, São Paulo, Madras, 2005; e Lucien Febvre, Michelet e a Renascença, op. cit. p. 402.
}

${ }^{14}$ Jean Flori, A Cavalaria, op. cit. p. 45. 
às instituições militares romanas. Contudo, a tese mais aceita é a de que seus principais fundamentos são de origem teutônica.

Durante as Cruzadas, a Igreja criou várias ordens de cavalaria, com o propósito de proteção das fronteiras naturais da Cristandade. Com o fim das Cruzadas, as ordens cavaleirescas europeias perderam muito do seu campo de ação. Tornando-se parcialmente ociosas, seus combates se restringiram à participação na luta contra os infiéis, na guerra de Reconquista da Espanha. Foi preciso buscar novas funções sociais para guerreiros desocupados. Em parte, os torneios criados no espaço vazio deixado pelas Cruzadas, reduziram a pressão negativa exercida pelos cavaleiros entre os demais segmentos da sociedade feudal. Contudo, até os finais do século XII, os torneios eram uma espécie de "réplica codificada" das guerras de verdade, o que levou a Igreja a se manifestar contra a realização dessas atividades. ${ }^{15}$ Mas, houve aí um processo civilizador. Como explica um escritor do Antigo Regime, "a ideia de paladinos protetores da virtude e da beleza das mulheres levou à noção de galanteria. Esse espírito perpetuou-se pela prática dos torneios, que, unindo ao mesmo tempo os direitos do valor e do amor, deram também à galanteria uma grande importância." ${ }^{16}$ A Igreja se engajou na civilização dos costumes de homens cuja força física era inversamente proporcional ao conhecimento e à cultura.

Como afirma Johan Huizinga, “(...) o pensamento medieval não permitia formas ideais de nobreza independentes da religião. Por essa razão a piedade e a virtude têm de ser a essência da vida do cavaleiro. A cavalaria, porém, nunca virá a realizar perfeitamente esta função ética. A sua origem terrena impede-a”. ${ }^{17}$ Tanto isso é um dado de realidade que a história da cavalaria, se é composta por idealismo e nobres princípios, inclui também muita força bruta e complexas maquinações políticas. Os confrontos entre o rei francês Filipe, o Belo, e a ordem dos Templários, demonstram a dureza desses conflitos, em que entrava em jogo algo mais do que profissões de fé. Em meio a uma crise aguda das finanças, o monarca quis se apossar do patrimônio da Ordem. As diferenças entre o monarca e os

${ }^{15}$ Cf. J. Flori, "Cavalaria”, In: Jean Claude Schmitt \& Jacques Le Goff, op. cit., p. 195. Cf também Georges Duby, Guilherme Marechal, Rio de Janeiro, Graal, 1987. Do mesmo autor, ver ainda: A Sociedade Cavaleiresca, São Paulo, Martins Fontes, 1989.

${ }^{16}$ Montesquieu, Do Espírito das Leis, p. 435.

${ }^{17}$ Johan Huizinga, “A ideia da cavalaria”. In: O declínio da Idade Média, São Paulo, Verbo/Edusp, 1978. p. 65. 
Templários culminaram com a condenação de Jacques de Molay e demais eminências da ordem à fogueira no início do ano de $1314 .{ }^{18}$

A literatura cavaleiresca dos séculos XII e XIII constitui-se em fonte histórica reveladora tanto do ambiente de criação intelectual como das relações entre setores leigos e clericais nos fins da Idade Média: "Les romans nous décrivent la société chevaleresque de l'époque, ocupée aux tournois qui ont remplacé la guerre privée et les pillages des époques antérieures." ${ }^{19} \mathrm{O}$ romance de cavalaria foi o primeiro gênero literário de alcance continental escrito nas línguas vernáculas emergentes. Mas foi além da Europa. No tempo das grandes navegações, romances cavaleirescos desembarcaram nas Américas. No século XVI, livros de cavalaria chegavam às Índias de Castela nas mãos dos conquistadores espanhóis, conforme afirma Sérgio Buarque de Holanda. Segundo ele, "é fora de dúvida que os romances de cavalaria constituíram a leitura dileta e a inspiração de muitos conquistadores espanhóis”. ${ }^{20} \mathrm{E}$ essa inspiração foi fonte alimentadora de nossa literatura romântica. Como o próprio Sérgio Buarque analisa, em outro livro, ao explicar o espírito empreendedor típico do colonizador português - pautado pela aventura e a intemperança -, a conversão de símbolos literários medievais europeus para uma adaptação nos trópicos marcou a vida intelectual no Brasil imperial. Em Raízes do Brasil, o historiador aponta o esforço da produção literária em ajustar os costumes heróicos dos guerreiros da Idade Média à bravura natural dos aborígines: “(...) escritores do século passado, como Gonçalves Dias e Alencar, iriam reservar ao índio virtudes convencionais de antigos fidalgos e cavaleiros, ao passo que o negro devia contentar-se, no melhor dos casos, com a posição de vítima submissa ou rebelde." ${ }^{21}$

Muito mais tarde, os romances de cavalaria reviveriam no fascínio de algumas nações europeias por seu passado. E a cavalaria medieval voltou a fazer época. $\mathrm{Na}$ França, no auge do romantismo - primeira metade do século XIX —, houve uma, por assim dizer, ressurreição do gênero romance de cavalaria. No tempo de

\footnotetext{
${ }^{18}$ Cf. Pedro Silva, História e mistérios dos Templários, Rio de Janeiro, Ediouro, 2001, p. 65s.

${ }^{19}$ Robert Fawtier, “L’expression française”, In: René Grousset \& Emile Leonard, De l'Islam à la Reforme, Paris, Gallimard, 1957, p. 785.

${ }^{20}$ Sérgio Buarque de Holanda, Visão do paraíso, São Paulo, Brasiliense, 1994, p. 33. Para a presença dos romances de cavalaria deste lado do Atlântico em período mais recente, ler: Peter Burke. "A cavalaria no Novo Mundo". In: Variedades de história cultural, Rio de Janeiro, Civilização Brasileira, 2000.

${ }^{21}$ Sérgio Buarque de Holanda, Raízes do Brasil, São Paulo, Companhia das Letras, 1999. p. 56.
} 
Michelet, reeditaram-se abundantemente esses livros. Inspirados nessa literatura, alguns romances históricos do século XIX se esforçaram por recriar ações espetaculares de personagens da cavalaria medieval. Foi com o escritor escocês Walter Scott que o romance histórico nasceu. Ivanhoe, de 1820, foi o primeiro romance histórico do romantismo. ${ }^{22} \mathrm{O}$ romance histórico foi a forma de expressar, literariamente, esses sentimentos, numa época marcada pela ascensão dos nacionalismos. O romantismo carregou o gênero de valores nacionalistas e se tornou atraente, tanto para os círculos nobiliárquicos em refluxo, como se constituiu também em matéria de interesse da burguesia ascendente. Seu rastro de sucesso foi seguido por autores como Prosper Merimée, Alfred de Vigny e Victor Hugo. No século XIX, diversas culturas nacionais europeias celebraram essa temática.

O sucesso de Ivanhoe foi tanto que valeu a seu autor um título nobiliárquico. O livro é pura exaltação da Idade Média, do heroísmo saxão, dos castelos, e das aventuras cavaleirescas do século XII: "O amor à luta é o alimento que nos anima; o pó da mêlée é como o ar para nossos pulmões! Não vivemos nem desejamos viver senão para ser vitoriosos e cobrir-nos de glória... Tais são as leis da cavalaria, a que juramos obedecer e a que sacrificamos tudo o que nos é mais caro", desabafa o cavaleiro saxão Wilfred de Ivanhoé. ${ }^{23}$ A obra de Walter Scott é expressão da nostalgia do tempo do autor por suas origens, tempo esse que tendeu a valorizar a Idade Média como um mundo portador de virtudes heróicas expressas por paixões fortes e espontâneas, aquelas pulsões violentas analisadas por Norbert Elias. ${ }^{24}$ No livro de Scott, de forma surpreendente e bastante curiosa, os vilões e bandoleiros quase anônimos são figuras muitíssimo mais proeminentes que o suposto herói que dá título ao romance. O saco de maldades do cavaleiro templário Brian de Bois Guilbert ocupa um papel incomensuravelmente mais destacado que as ralas cenas de bravura protagonizadas por Wilfred de Ivanhoé

${ }^{22}$ Acerca do nascimento do romance histórico há quem, mutatis mutandis, encontre raízes bem mais profundas: Cf. Le Goff, "Naissance do roman historique au XII Siècle", In: Nouvelle Revue Française, Paris, 1972. p. 163. Acerca do nascimento do gênero romance histórico no século XIX e sobre a obra fundadora de Walter Scott ler: Georg Lukács, Le roman historique, Paris, Payot, 1965.

${ }^{23} \mathrm{E}$ o autor prossegue por meio de seu personagem: "A cavalaria! É ela que alimenta os afetos mais nobres e puros, que repara as injustiças, que permanece ao lado dos oprimidos, que domina o poder do tirano! Sem ela, a nobreza seria uma palavra sem sentido, e é em sua lança e em sua espada que a liberdade encontra a sua melhor proteção". Walter Scott, Ivanhoé, São Paulo, Círculo do Livro, 1995, 394s.

${ }^{24}$ Norbert Elias, O processo civlizador: uma história dos costumes, Rio de Janeiro, Zahar, 1990, vol. 1. 
que, aliás, faz figura de herói ausente, passando a maior parte da narrativa oculto sob o manto de um peregrino ou como guerreiro ferido e imobilizado.

Nos fins da Idade Média, o romance de cavalaria foi a prosa de ficção de maior sucesso de público, num tempo que viu nascer e frutificar gêneros literários variados. O historiador Edouard Perroy dá uma boa medida da riqueza da criação literária no período final da Idade Média francesa: "Miroirs d'une société, le roman de chevalerie, le conte allégorique, le récit d'histoire ou le lyrisme courtois s'adressent à une aristocratie qui reste fière de son passé." ${ }^{25}$ Sem dúvida, o gênero agradava aos homens e às mulheres, pelo conteúdo fantástico das façanhas de seus protagonistas, em meio a sociedades que cultivavam o herói guerreiro como figura máxima das virtudes cristãs e que, acima de tudo, era opositor e vencedor infalível de infiéis, de bandidos e de monstros.

O paladino da história cavaleiresca é quase sempre uma espécie de Ulisses cristianizado, o justiceiro que vai salvar a sua amada e o seu povo das ações de usurpadores. Naturalmente, a ação militar exercia fascínio entre homens de costumes rústicos, e o conteúdo romântico da narrativa atingia em cheio o coração das donzelas sonhadoras. Como demonstrou Huizinga, havia algo mais que força e ferocidade nessa literatura: "O cavaleiro e sua dama, ou, por outras palavras, $o$ herói que serve por amor - é este o motivo primário e invariável de onde a fantasia erótica partirá sempre. É a sensualidade transformada em ânsia de sacrifício, no desejo revelado pelo macho de mostrar a sua coragem, de correr perigos, de ser forte, de sofrer e sangrar diante da amada." 26

Em uma perspectiva abrangente do gênero, pode-se afirmar que os romances de cavalaria foram variações de um só enredo. Eles sempre realçavam as vitórias gloriosas do herói sobre os opressores dos desvalidos. Decorrido um certo tempo da narrativa, ouve-se apenas o pranto dos inocentes oprimidos pelos sequazes de algum poderoso de péssima índole, até que o paladino toma ciência das injustiças cometidas. Daí em diante, é a escalada da mais pura energia virtuosa, um verdadeiro festival de punições dos agravos, uma torrente de força que restaura a ordem natural das coisas. Essa base de heroísmo é acrescida de uma complicada trama romanesca cheia de interditos e desencontros amorosos. Isso porque,

\footnotetext{
${ }^{25}$ Edouard Perroy, "Les transformations de la société chevaleresque", In: Histoire de la France, Paris, Gallimard, 1950, p. 148.

${ }^{26}$ Johan Huizinga, “O sonho do heroísmo e do amor”. in: op. cit., p. 74.
} 
na composição do romance cavaleiresco, não pode faltar uma intensa paixão, daquelas que removem montanhas.

A presença de uma dama de excepcional beleza é um dos elementos vitais da estrutura do romance, e ainda mais na última fase dessa literatura, na qual se acentua a galanteria. À beleza superlativa da mulher é preciso acrescentar as virtudes do sexo frágil: fidelidade e pureza em primeiro plano. A figura feminina era indispensável ao cavaleiro, porque só se realizavam verdadeiras façanhas se existisse o combustível da paixão por uma donzela. A única recompensa em jogo era a "resposta" que o cavaleiro receberia da dama de seus pensamentos. Mas, junto com as experiências fantásticas, foi o erotismo o elemento que, na composição do romance, acrescentou os diferenciais que livraram o gênero da toada monocórdia das façanhas de armas dos cavaleiros. Por sua amada, os cavaleiros faziam promessas como, por exemplo, andar com um dos olhos vendados, enquanto não conseguissem dar cabo de uma proeza; por ela deixa-se crescer a barba, à espera da realização de um feito de armas etc. Ainda que por outros motivos, Chrétien de Troyes deu testemunho dessas punições autoimpostas. Seu personagem Parcifal - que pertence à fase do ciclo arturiano, também conhecido como "Matéria da Bretanha”, devido à centralidade do rei Arthur e ao predomínio das lendas célticas -, além de recusar-se a dormir duas noites seguidas sob um mesmo teto, participou, durante cinco anos inteiros, nas mais arriscadas aventuras.

As recorrências do fantástico e do maravilhoso - monstros, espíritos, gigantes - completam o tripé dos motivos dessa literatura, que não sabia distinguir o que era realidade efetiva e o que pertencia à criação ficcional: o real e o figurativo se fundiam num mesmo conjunto de alegorias. Para Jacques Le Goff, "os romances do século XII são, de fato, "simbólicos", no sentido de que os seus autores nos falam do "sem" (sentido) escondido dos seus poemas". ${ }^{27}$ Esse tipo de operação intelectual é reconhecido por teóricos da literatura como o recurso da alegoria, como uma "interpretação figural" (Auerbach), em que a realidade histórica cede espaço à pura construção de um sentido peculiar ao universo cultural do autor. Como afirma Antoine Compagnon, "a alegoria é uma interpretação anacrônica do passado, uma leitura do antigo, segundo o modelo do novo, um ato hermenêutico de apropriação: à intenção antiga ela substitui a dos leitores. (...) A alegoria é um

${ }^{27}$ Jacques Le Goff, “Esboço de análise de um romance cortês”, in: op. cit., p. 129. 
instrumento todo poderoso para inferir um sentido novo num texto antigo". ${ }^{28} \mathrm{Na}$ análise de Erich Auerbach, "durante a Idade Média europeia era possível, ainda, representar os acontecimentos bíblicos como sucessos quotidianos contemporâneos, para o que o método exegético fornecia as bases". ${ }^{29}$ Sob a perspectiva de Auerbach - que está focada na literatura medieval, e mais especificamente na obra de Santo Agostinho - "o acontecimento sensorial empalidece, sobrepujado pela significação figurada". ${ }^{30}$ Assim, conceitos como o de "significação figurada" são úteis para a compreensão dos anacronismos que aparecem, por exemplo, na famosa Canção de Rolando, da qual se falará adiante.

A base de apoio do romance cortês é constituída por heroísmo, amor e aventura. Como afirmado acima, o gênero era um sucesso de público em toda a Europa, e mais ainda quando passou a ser escrito em prosa. Segundo Otto Maria Carpeaux,

a prosa, em vez do verso, facilita muito a tradução, torna possível a surpreendente divulgação internacional dos romans courtois por todas as nações, em todas as literaturas, da Espanha à Islândia, da Inglaterra à Bulgária. (...) Romans courtois em verso e romans courtois em prosa, juntos, constituem a literatura internacional da época. ${ }^{31}$

Mas qual era o público dessa literatura? O historiador holandês Johan Huizinga esclarece que eram escassos os círculos de leitores dos romances de cavalaria, uma vez que "o ideal da elegante vida heróica só podia ser cultivado dentro dos limites de uma casta fechada". ${ }^{32} \mathrm{Na}$ avaliação de Jacques Le Goff, "o romance, obra escrita e destinada a ser lida, exclui deliberadamente o público misto que escutava as chansons de geste. Só as duas ordens maiores, chevalerie e clergie, são comensais do romance". ${ }^{33}$ Tratou-se, portanto, de um gênero destinado à fruição das elites, de uma literatura a ser desfrutada nos castelos e que, segundo a ironia de Voltaire, destinava-se a preencher o vazio da existência e a alimentar a imaginação de

\footnotetext{
${ }^{28}$ Antoine Compagnon, O demônio da teoria: literatura e senso comum, Belo Horizonte, Editora UFMG, 2001. p. 56s.

${ }^{29}$ Eric Auerbac, Mimesis: a representação da realidade na literatura ocidental, São Paulo, Perspectiva, 2002. p. 12 s.

${ }^{30} I d$. ib., p. 41.

${ }^{31}$ Otto Maria Carpeaux, História da literatura ocidental, Rio de Janeiro, Edições O Cruzeiro, 1959, p. 298. Para uma outra ampla análise sobre o tema ler ainda: Arnold Hauser, "O romantismo da cavalaria cortesã”. In: História social da arte e da literatura, São Paulo, Martins Fontes, 2003, p. 195ss.

${ }^{32}$ Johan Huizinga, "O valor político e militar das ideias da cavalaria”. in: op. cit., p. 89.

${ }^{33}$ Jacques Le Goff, “Esboço de análise de um romance cortês”, in: op. cit., p. 148.
} 
aristocratas ociosos em suas longas tardes de inverno. Foi a "imaginação criativa" nascida e impulsionada por essa literatura dos castelos o que propiciou, segundo o filósofo iluminista, a aparição dos tratados de demonologia e todo um cortejo abundante de fantasmagorias literárias, para a vergonha do gênero humano.

Tendo possuído uma longa existência histórica, o motivo central dessa literatura genuinamente cristã - já que, do ponto de vista de sua estrutura formal, não possuiu antecedentes clássicos como a tragédia, por exemplo - são as façanhas de algum indivíduo cuja têmpera excepcional o credencia a protagonizar ações inconcebíveis a um homem comum. Serão essas virtudes hipertrofiadas do herói da Idade Média o elemento central para o descrédito desse gênero de romance a partir dos inícios do século XVIII, com a aparição de um público leitor interessado em tramas mais próximas das dimensões existenciais da vida.

Em seu tempo, o romance de cavalaria conviveu com outros gêneros de literatura. Como diz Jacques Le Goff, as chansons de geste surgiram no Ocidente medieval um pouco antes dos romances corteses, mas ao longo do século XII os dois gêneros conviveram, interferiram mutuamente e fizeram concorrência entre si. ${ }^{34}$ Do ponto de vista temporal, o romance de cavalaria foi uma espécie de sucessor da canção de gesta. Mas não apenas isso. Ele incorporou alterações de conteúdo, como a substituição do tema épico da luta contra infiéis, exaltando muito mais as dimensões mundanas da vida. Do ponto de vista da estrutura temática, as canções de gesta foram o que existiu de mais próximo. Entretanto, os romances de cavalaria se diferenciam das canções de gesta por não se ocuparem das ações heróicas de uma comunidade inteira, em luta pela preservação de sua independência, de sua identidade e da continuidade de sua existência, como é o caso da Canção de Rolando. Essa trama foi transformada pela tradição oral em conflito entre cristãos e muçulmanos quando, na verdade, Rolando, sobrinho de Carlos Magno, fora atacado por montanheses bascos no desfiladeiro de Roncesvales, região dos Pireneus.

O episódio ocorreu no ano de 788. Na Canção de Rolando, de autoria desconhecida e que data do século XII, conta-se que este par de França fora atraiçoado por Ganelon, outro nobre do exército do imperador que, por ódio a Rolando, permitiu que o exército do rei de Saragoça, Marsile, cercasse a retaguarda do

${ }^{34}$ Cf. Jacques Le Goff, "Naissance do roman historique au XII Siècle", in: Nouvelle Revue Française, op. cit. 
exército dos francos. A ficção narra o heroísmo de Rolando que, comandando a retaguarda, não permite que se toque a trombeta, como aviso à vanguarda do exército de Carlos Magno, que marchava alguns quilômetros à frente. Segundo a lenda, o herói e seus vinte mil soldados francos enfrentavam e venciam parcialmente um colosso de quatrocentos mil sarracenos. Mas Rolando foi ferido mortalmente, como também pereceram em Roncesvales os demais pares de França. A vitória final contra os sarracenos foi alcançada por Carlos Magno, em Aix-laChapelle. O traidor Ganelon foi esquartejado.

$\mathrm{Na}$ Canção de Rolando, a acumulação desvirtuada de acontecimentos reais e valores culturais está bem de acordo com as ideias de história, conforme eram concebidas na Idade Média. Há muitas transposições livres de ideias no tempo, ideias essas que nunca pertenceram à época e à cultura descritas. Tais ideias foram inseridas por narradores situados muito distantes de acontecimentos, acerca dos quais nada se falou por mais de meio século após o episódio. Como afirma Otto Maria Carpeaux, "os costumes que a epopeia apresenta são um grande anacronismo; os guerreiros do século VIII aparecem como cavaleiros feudais; está em contradição com isso o exagero, evidentemente primitivo, das forças físicas e das façanhas corporais" ${ }^{35}$ Em síntese, a narrativa - cuja versão definitiva é o manuscrito de Oxford, do ano de 1120 - já fala dos franceses numa época em que eles ainda não existiam verdadeiramente.

De todo modo, as tramas das canções de gesta - essas "Ilíadas em potência", conforme a definição de Jean-Pierre Bayard ${ }^{36}$ - são temas históricos que, fixados pela memória coletiva, vão ganhando com o tempo novos e surpreendentes sentidos. Já no romance de cavalaria, além dos autores se aterem exclusivamente a um plano de ações individuais, a narrativa é um relato ficcional, sem necessariamente apelar para uma realidade histórica. ${ }^{37} \mathrm{O}$ seu motivo é constituído pelas venturas e adversidades de um paladino, tendo como combustível o amor cortês. Os finais felizes dos romances de cavalaria - norma suprema do gênero - são a realização plena das paixões impossíveis narradas. E o melhor exemplo é aquele que foi o livro de cabeceira de Dom Quixote: Amadis de Gaula.

\footnotetext{
${ }^{35}$ Otto Maria Carpeaux, op. cit., p. 250.

${ }^{36}$ Jean-Pierre Bayard, Histoire des légendes, Paris, PUF, 1955.

${ }^{37}$ Cf. Georges Duby, “Au XIIe. Siècle: les 'jeunes' dans la société aristocratique”, in: Annales ESC, Paris, 1964, p. 844.
} 
Nesse romance, são enormes e praticamente intransponíveis as barreiras impostas pelos códigos nobiliárquicos a um personagem desfavorecido pela complexa rede hierárquica de seu mundo. Amadis - o herói preferido do personagem de Cervantes - era filho natural do rei de Gales. Somente as formidáveis proezas do cavaleiro bastardo, numa sociedade marcada por valores aristocráticos rígidos, poderiam lhe valer uma vaga esperança de conquistar o coração da princesa Oriana. É pouco o que se sabe acerca da autoria do Amadis de Gaula, a mais célebre obra da terceira fase da cavalaria medieval. ${ }^{38}$ Amadis de Gaula é avaliada como a obra que alcançou a maior perfeição no gênero. A Vasco de Lobeira, escritor galego que viveu no século XIII, é atribuída a paternidade do romance. No entanto, a primeira edição de que se tem notícia é espanhola, dos inícios do século XV. A edição definitiva do Amadis foi fixada por Garci Rodríguez de Montalvo, em 1508.

Segundo García López, é certo que existiu uma versão original do Amadis de Gaula no século XIII ou XIV. Autores desse período atestam ter lido a obra em sua estrutura primitiva, ou seja, da forma como a havia concebido Vasco de Lobeira. Mas ela alcançou o século XV apenas em fragmentos. ${ }^{39}$ Montalvo deu sua própria contribuição ao que restou da versão original, acrescendo-a de mais duas partes de sua própria lavra. O resultado das filtragens, interpolações e expansões de Montalvo foi um sucesso retumbante. A excelência das virtudes do Cavaleiro do Leão, a síntese maior da fidelidade no amor, ajudam a explicar a calorosa recepção de tantas gerações de leitores espanhóis.

É quase certo que a referência ao leão seja reflexo da influência da obra de Chrétien de Troyes, Yvain ou le Chevalier au Lion, datada de fins do século XII, por volta do ano de 1180. A presença de animais como cognome de cavaleiros - o Cavaleiro do Falcão, do Cisne etc. - revela as dimensões do fantástico no romance de cavalaria, ao pontuar alguma experiência heróica do guerreiro com um animal temível ou que lhe apresente sérios riscos de morte. Na ironia de Cervantes, foi o que ocorreu com Dom Quixote, quando ordenou que abrissem a carroça dos famélicos leões de circo. Como nenhum deles se aventurou a sair da jaula em busca de tão "atraente" presa, o valoroso cavaleiro logo os deu por ven-

\footnotetext{
${ }^{38}$ A primeira fase foi a da época de Carlos Magno ao século XI, muito marcada pela violência e a indisciplina, ainda que esses traços sejam característicos das demais fases. A segunda fase coincidiu com o início das Cruzadas, com os já firmemente definidos ideais cristãos de defesa da fé. A última fase se estendeu do século XII até o XV e foi marcada pelo espírito galante e o amor cortês.

${ }^{39}$ Cf. José García López, “La prosa didáctica, la novela y la historia em el siglo XV”, op. cit., p. 130.
} 
cidos, pelo terror que o seu braço forte lhes causara. Foi quando quis tornar-se conhecido como "el Caballero de los Leones", diz o próprio Dom Quixote, "que de aquí adelante quiero que éste se trueque, cambie, vuelva e mude el que hasta aquí he tenido del Caballero de la Triste Figura; y en esto sigo la antigua usanza de los andantes caballeros, que se mudaban los nombres cuando querián o cuando les venía a cuento". ${ }^{40}$ Isso para dizer que o cavaleiro andante era frequentemente atacado por dragões, leões ou serpentes, cada qual representando um simbolismo complexo. No caso de Dom Quixote, o dito simbolismo complexo é alvejado por uma descarga de ironia. Assim, o elemento de curiosidade nesse episódio é que os dois leões estavam famintos, e, mesmo assim, não se resolveram a sair. Pode ser que a presa, por demais esguia, não lhes parecesse compensar a corrida. Talvez Cervantes também tenha pretendido mostrar que nem mesmo feras esfaimadas ainda levavam a sério os cavaleiros andantes. Ao menos, é o que parece sugerir o autor, entre outras possibilidades de interpretação da cena. ${ }^{41}$

Amadis é um tipo de herói no qual se fundem os mais peregrinos valores da cavalaria andante, como a força, a fidelidade, a coragem, a fé etc. A sua personalidade é forte em todos os fundamentos morais. Não há um calcanhar de Aquiles a ressaltar-lhe um mínimo defeito ou qualquer sombra de imperfeição, como no caso do bravo Lancelote, que, por causa de seu amor sacrílego a Guinevère, tornara-se incapacitado para triunfar na demanda do Santo Graal. Assim, não se concebe em nenhum outro modelo, a elevação de princípios desse cavaleiro, símbolo da pureza, reflexo das virtudes de Galahad. Sua bravura é tão evidente, sua força é tão superior, sua paixão é tão casta, a ponto de torná-lo sem rival entre os maiores paladinos de toda a história da cavalaria.

O amor idealizado do príncipe bastardo não revela os traços bem pronunciados daquela sensualidade típica dos romances de cavalaria tradicionais da Idade Média. Talvez, a atmosfera carregada de religiosidade da Contra-Reforma - contexto de circulação da obra - tenha induzido os leitores a enxergar nessa castidade do personagem Amadis um elemento de admiração. De fato, o maior sucesso da obra coincide com o século XVI, o tempo das novas "cruzadas" de Carlos V contra os protestantes, mas também a época das fogueiras de Filipe II

\footnotetext{
${ }^{40}$ Miguel de Cervantes, Don Quijote de la Mancha, Madrid, Real Academia Espãnola, 2004. p. 677.

${ }^{41}$ A propósito, ver o estudo de Otto Maria Carpeaux, Cervantes e o leão. In: Sobre Letras e Artes. São Paulo, Nova Alexandria, 1992.
} 
aos desgarrados da fé. Esse, por assim dizer, puritanismo do personagem Amadis, parece ter sido um traço muito adequado aos severos tempos do rei Filipe II, época que viu nascer e tomar corpo uma poderosa onda de misticismo. No plano dos sentimentos descritos no Amadis de Gaula, tem-se uma prova do grau de paixão concentrada do personagem por sua donzela: seu amor pela princesa Oriana é tão intenso que, em certa ocasião, ele desmaiou apenas ao ouvir alguém pronunciar o seu nome.

Como traço específico do gênero, o romance de cavalaria possuiu uma vigorosa capacidade de expansão de suas tramas. A natureza essencialmente narrativa do romance cavaleiresco era muito favorável a desdobramentos da história, dependendo apenas do sucesso alcançado pela obra. Assim, novas aventuras de um mesmo personagem eram contadas em livros sucessivos, normalmente intitulados "as novas aventuras de...." ${ }^{42}$ Naturalmente, essa elasticidade do tema, ou melhor, essa capacidade desmedida de expansão de uma história, tendia a gerar livros de proporções colossais em vários volumes. Mas essas estórias sem fim não esgotavam a paciência do público leitor, conforme explica Abel Lefranc: "Desfrutando de ócios que hoje ignoramos, apaixonavam-se por essas existências aventurosas, deixavam-se embalar por todas aquelas fábulas e seguiam através de um mundo encantado os heróis criados pela imaginação." ${ }^{43}$ As muitas derivações do Amadis de Gaula são prova disso. Ao todo, fizeram-se mais nove partes autônomas da obra, por iniciativa de diferentes autores espanhóis ao longo do século XVI. ${ }^{44}$

$\mathrm{Na}$ Espanha, o entusiasmo pelo livro gerou um sem número de imitações oportunistas como, por exemplo, o Belianis da Grécia, o Olivante de Laura, e a trilogia anônima dos Palmerim, obras muito citadas por Cervantes. Rapidamente, o livro ganhou terreno internacional e, em 1512, surgiu uma tradução italiana. Na França, Amadis de Gaula fez enorme sucesso em meados do século XVI, em tradução de 1540, de autoria do nobre picardo Nicolas de Herberay, senhor des Essarts. A exemplo de Cervantes, Montaigne também revelou a sua repulsa ao gênero: "Quanto aos Amadis e outros romances do gênero, não me interessaram

\footnotetext{
${ }^{42}$ Sobre o tema ver: A. Duran, Estructura y técnicas de la novela sentimental e caballeresca, Madrid, Gredos, 1973.

${ }^{43}$ Abel Lefranc, "As leituras: os romances de cavalaria". In: A vida quotidiana no tempo do Renascimento, Lisboa, Livros do Brasil, s.d. p. 101s.

${ }^{44}$ Cf. José García López, "La prosa didáctica, la novela y la historia em el siglo XV”, op. cit., p. 130s.
} 
sequer quando os li em criança." ${ }^{45} \mathrm{O}$ sucesso da obra na pátria de Montaigne atravessou toda a segunda metade do século XVI e, nos finais do reinado de Henrique IV - inícios do século XVII - o livro ainda compunha a biblioteca ideal da aristocracia francesa. No tempo de Henrique IV, era comum se referir ao Amadis de Gaula como "a bíblia do rei”" ${ }^{46}$

Antes de concluir estas notas exploratórias, é preciso afirmar que o romance de cavalaria foi um gênero sincrético e cada livro era uma obra aberta que podia reunir, de modo orgânico, alguns traços do ideal aventureiro da antiga epopeia clássica, o sentimentalismo trovadoresco das canções de gesta, certos traços mundanos da literatura picaresca, bem como diversas dimensões de outras formas literárias. $\mathrm{O}$ romance cavaleiresco fundia ainda elementos sagrados e profanos: guerras, milagres, virtudes cristãs, amor e aventuras eram os principais ingredientes do gênero: "Littérature d'évasion hors du réel et du rationnel, suite d'aventures merveilleuses, amoureuses et guerrières, liées par le procédé du voyage dans le monde de rêve, de la 'quête'. Ces récits furent d'abord bâtis sur des canevas empruntés à la littérature antique (...)" ${ }^{47}$ Mas, para além dos motivos explorados pela imaginação, os romances de cavalaria possuíram outros sentidos e outras aplicações. Lucien Febvre explica a importância cultural e a função social dessa literatura: "Os romances de cavalaria não tratam única e exclusivamente do amor. Não tratam única e exclusivamente do casamento. Tratam de problemas tão graves na ordem política e nacional (...). Tratam da honra, e do ponto de honra. Elaboram e espalham uma moral da honra que é individualista em sua essência, e egotista." ${ }^{48}$

Os romances de cavalaria tiveram vida longa e atravessaram, como tradição literária vigorosa, quatro séculos de história. A partir dos séculos XV e XVI a emergência das monarquias europeias foi uma influência negativa para a vitalidade dessa literatura, simplesmente porque essas novas formas políticas tornaram anacrônicas algumas das funções sociais da cavalaria, principalmente o

\footnotetext{
${ }^{45}$ Michel de Montaigne, Ensaios, p. 197. Curiosamente, Ian Watt inclui Montaigne no elenco dos sábios e moralistas admiradores do Amadis. Cf. Ian Watt, Mitos do individualismo moderno, Rio de Janeiro, Zahar, 1997, p. 71.

${ }^{46}$ Acerca da fortuna crítica do Amadis na França ler Abel Lefranc. "As leituras: os romances de cavalaria", op. cit., p. 95ss.

${ }^{47}$ Georges Duby \& Robert Mandrou, "Le roman”, In: Histoire de la civilisation française. Moyen Age - XVIe. Siècle, Paris, Armand Colin, 1982, p. 131s.

${ }^{48}$ Lucien Febvre, Michelet e a Renascença, São Paulo, Scritta, 1995, p. 421.
} 
seu valor militar. Como afirma Ian Watt, "as cruzadas haviam terminado; e as novas técnicas militares, as novas armas e as novas formas organizacionais estavam transformando o cavaleiro coberto de ferro em uma relíquia do passado". ${ }^{49}$ Como também demonstrou Norbert Elias, a cavalaria não correspondia mais às necessidades da guerra. Com a nova relevância assumida pela infantaria nos campos de batalha, os outrora "desprezados soldados a pé", chega ao seu termo o "monopólio de armas" da cavalaria medieval..$^{50}$

Aos romances de cavalaria coube celebrar os triunfos de uma época que, dramaticamente, encerrou-se com Dom Quixote. Há quem pense que a idealização da vida dos cavaleiros na época do feudalismo já era, naquele tempo, um claro reflexo do decadentismo político dos barões feudais. Aos romances teria restado a tarefa de lustrar o prestígio perdido. Assim sendo, faz sentido a afirmação de Otto Maria Carpeaux, para quem o roman courtois integra aquele conjunto de obras que, antigamente, era lido com grande interesse e que, atualmente, não passa de uma espécie de ilustre defunto, "o canto mais abandonado do grande cemitério melancólico que é a história da literatura universal". ${ }^{51}$

Já em altura bem avançada da história, a nostalgia dos tempos idos ainda contagiava a aristocracia francesa do século XIX. Há muito encerrada a época das grandes aventuras dos cavaleiros, o romantismo ofereceu uma oportunidade para se acalentar as glórias dos nobres tempos de outrora. Sob esse aspecto, o testemunho literário de Stendhal, atento observador dos costumes de sua época, é uma fonte preciosa. Em O vermelho e o negro observa-se Julien Sorel - o pobre aldeão boa-pinta, promovido a secretário do influente Marquês de La Mole zombar de aristocratas passadistas que se jactavam de possuir antepassados que acompanharam São Luís nas Cruzadas. ${ }^{52}$

\footnotetext{
${ }^{49}$ Ian Watt, Mitos do individualismo moderno, p. 68.

${ }^{50}$ Cf. Norbert Elias, O processo civlizador: formação do Estado moderno, Rio de Janeiro, Zahar, 1993, vol. 2, p. 21.

${ }^{51}$ Otto Maria Carpeaux, História da literatura ocidental, p. 306.

${ }^{52}$ Cf. Stendhal, O vermelho e o negro, São Paulo, Abril Cultural, 1983. p. 308. Em A Cartuxa de Parma outro personagem de Stendhal se jacta de suas raízes aristocráticas. É o primeiro-ministro do príncipe de Parma, o Conde Mosca, na passagem em que se lê a seguinte reflexão do fiscal Rassi, o burguês invejoso e maníaco pela nobreza: “... o conde, muito orgulhoso de sua estirpe, só estimava a nobreza comprovada por títulos anteriores ao ano de 1400". Stendhal, A Cartuxa de Parma, São Paulo, Abril Cultural, 1984, p. 116.
} 